\title{
Growth, leaf biomass yield of stevia and post-harvest soil fertility as influenced by different levels of poultry manure
}

\author{
M. M. Zaman ${ }^{1}$, K. Nahar ${ }^{2}$, T. Chowdhury ${ }^{3}$ and M. A. H. Chowdhury ${ }^{2}$ \\ ${ }^{1}$ Soil Resources Development Institute, Farmgate, Dhaka, Bangladesh. \\ ${ }^{2}$ Department of Agricultural Chemistry, Bangladesh Agricultural University, Mymensingh-2202. Bangladesh \\ ${ }^{3}$ Department of Agricultural Chemistry, Sher-E-Bangla Agricultural University, Dhaka-1207, Bangladesh
}

\section{ARTICLE INFO}

Article history:

Received: 19 October 2017

Accepted: 26 November 2017

Keywords:

Stevia, Poultry manure, Leaf yield, Post-harvest soil

Correspondence:

M.A.H. Chowdhury

(akhterbau11@gmail.com )

\begin{abstract}
Stevia represents an interesting species for the development of new ingredients characterized by a low caloric contribution having high antioxidant and phytochemical properties. As a valuable organic fertilizer, poultry manure (PM) serves as a suitable alternate to chemical fertilizer due to having higher total solid content than most other manures. The present study was conducted in the net house of the Department of Agricultural Chemistry, Bangladesh Agricultural University, Mymensingh to evaluate the effects of poultry manure on growth and leaf yield of stevia and post-harvest soil fertility. The experiment was laid out in a Complete Randomized Design (CRD) with three replications. PM was applied at rates of 0, 5, 7.5 and $10 \mathrm{t} \mathrm{ha}^{-1}$. Data of the plant height, number of branches and number of leaves per plant were collected at $0,15,30,45$ and 60 days after planting (DAP). At harvest, leaf area, fresh weight, dry weight of leaves of stevia and post-harvest soil were evaluated. Plant that received $5 \mathrm{tha}^{-1}$ of PM was the best with respect to all the parameters assessed except post-harvest soil fertility. The contents of total $\mathrm{N}$, available $\mathrm{P}$, exchangeable $\mathrm{K}, \mathrm{Ca}, \mathrm{Mg}$, available $\mathrm{S}, \mathrm{Zn}$ and $\mathrm{B}$ were significantly increased with the increased levels of $\mathrm{PM}$ up to $10 \mathrm{t} \mathrm{ha}^{-1}$ in both soils. $\mathrm{pH}$ and soil organic matter content were also increased several folds and favored higher growth and yield of stevia. It can be recommended from the findings of the study that farmers should apply PM @ $5 \mathrm{t} \mathrm{ha}^{-1}$ to obtain maximum growth and leaf yield of stevia where as PM @ $10 \mathrm{tha}^{-1}$ can be applied for maintaining soil fertility in the agro-climatic condition of Bangladesh.
\end{abstract}

\section{Introduction}

In recent years, it becomes the major concern to longrun agricultural sustainability and ensure global food needs with the global population projected to exceed 7.5 billion by the year 2020 and 9.2 billion by 2050 (Gruhn et al., 2000). The long-term and intensive use of synthetic chemical fertilizers is hazardous to human health, soil productivity, water quality, aquatic life and environmental safety. Organic agriculture is a low-input sustainable agricultural production management system that promotes the environmentally, socially and economically sound production of food, fiber, timber etc (IFOAM, 2008). A traditional source of soil organic matter and primary nutrients for agricultural crops is the wide use of poultry manure in Bangladesh.

Poultry manure (PM) is a valuable organic fertilizer and can serve as a suitable alternate to chemical fertilizer. In agriculture, the main reasons for applying PM include the organic amendment of soil and the provision of nutrients to crops (Warren et al., 2006). PM application registered over $53 \%$ increases of $\mathrm{N}$ level in the soil, from 0.09 to $0.14 \%$ and exchangeable cations increase with manure application (Boateng et al., 2006). Stefan (2003) indicated that fresh poultry dropping contained $70 \%$ water, $1.4 \% \mathrm{~N}, 1.1 \% \mathrm{P}_{2} \mathrm{O}_{5}$ and $0.5 \% \mathrm{~K}_{2} \mathrm{O}$ while dried PM contained $13 \%$ water, $3.6 \% \mathrm{~N}, 3.5 \% \mathrm{P}_{2} \mathrm{O}_{5}$ and $1.6 \%$ $\mathrm{K}_{2} \mathrm{O}$. Manure not only provides high nutrient contents $(\mathrm{N}, \mathrm{P}$, and $\mathrm{K})$ in comparison with chemical fertilizer, but also adds organic matters to the soil for the improvement of soil structure, aeration, soil moisture-holding capacity, and water infiltration. Many studies indicated that using PM over a long period of time would change the biological and chemical properties of the soil with the increase of soil organic matter (Whalen et al., 2000; Yang et al., 2004; Moore and Edwards, 2005; Tejada et al., 2006; Varvel, 2006). Soil organic content supplied from PM affects greatly the physical condition of the soil such as runoff, infiltration, water retention capacity, soil $\mathrm{pH}$ and so on (Hillel, 1998). The application rates of PM and types of PM (broiler or litter) play the main role on soil properties (Gilley et al., 2000).

Increasing demand for dietetic products and natural food ingredients draw attention towards dietary natural antioxidants (Lobo et. al., 2010), capable to inhibit reactive oxygen species (ROS), responsible for the determination of several human pathologies, such as cancer, diabetes, cardiovascular diseases etc. At the same time, the increasing health concern over the consumption of sugar and the problems related to the safety of some artificial non nutritive sweeteners (NNS) have stimulated the interest toward natural sweeteners (Pawar et al., 2013). Stevioside and other steviol glycosides extracted from the leaves of the plant Stevia rebaudiana Bertoni were the first natural high potency sweeteners to be approved for consumption in the United States, the European Union (Risso et al., 2014), 
as well as in Australia and New Zealand. Nowadays it becomes an interesting species due to containing low calorie having high antioxidant and phytochemical properties. It is well known how the biosynthesis of secondary metabolites in medicinal plants is strongly influenced by several pre-harvest factors, such as environmental conditions, agricultural management, harvest time, water and nutrient requirements.

To best of our knowledge, till now no detailed study has yet been investigated about the agronomic management practices, ecological and nutrient requirements of stevia cultivation in Bangladesh. Some preliminary experiments on morphological and physiological parameter have been conducted by BSRI and brac. In Bangladesh Agricultural University recently some study has been conducted and reported on suitable soils (Zaman et al., 2015a), $\mathrm{N}$ and $\mathrm{S}$ requirement, critical $\mathrm{N}$ and S content (Zaman et al., 2016a and 2016b), vermicompost as organic manure (Zaman et al., 2015b) and $\mathrm{P}$ use efficiency and critical $\mathrm{P}$ content; $\mathrm{K}$ requirement and $\mathrm{K}$ nutrition (Zaman et al., 2017a and $2017 b$ ) in stevia grown in both acid and non-calcareous soil. Moreover, information on the effects of PM as a source of plant nutrients is scanty. Thus, according to the importance of phytochemicals and antioxidant power for functional aspect of stevia, the present study was conducted to evaluate the effects of PM on growth and yield of leaf biomass as well as the post-harvest status of stevia cultivated soil.

\section{Materials and Methods}

A pot experiment was conducted during February to May, 2012 under net house condition at the Department of Agricultural Chemistry, Bangladesh Agricultural University, Mymensingh. Stevia was grown in 24 pots containing two contrasting soil (acid and non-calcareous soils) treated with different rates of poultry manure (PM) viz., $\mathrm{PM}_{0}$ (without PM); $\mathrm{PM}_{5}\left(5 \mathrm{~kg} \mathrm{PM} \mathrm{ha}{ }^{-1}\right) ; \mathrm{PM}_{7.5}(7.5$ $\left.\mathrm{kg} \mathrm{PM} \mathrm{ha}{ }^{-1}\right)$ and $\mathrm{PM}_{10}\left(10 \mathrm{~kg} \mathrm{PM} \mathrm{ha}{ }^{-1}\right)$. PM contained $17.86,2.50,1.62,0.72,0.25,0.20$ and $0.019 \%$ organic $\mathrm{C}$, total $\mathrm{N}, \mathrm{P}, \mathrm{K}, \mathrm{S}, \mathrm{Ca}$ and $\mathrm{Mg}$, respectively. Each earthen pot was filled with $8.0 \mathrm{~kg}$ of processed soil. Soils used in this study were collected from Madhupur (Tangail) and BAU campus (Mymensingh). The experimental set up was done in Complete Randomized Design (CRD) with three replications. Stevia (Stevia rebaudiana Bertoni) seedlings of 45 day old, belonging to brac Biotechnology Laboratory, Joydebpur, Gazipur, were used. Physicochemical properties of both soils were measured (Zaman et al., 2015a). Initially small amount of urea was added to each pot including control. Time to time necessary intercultural operations were done viz., irrigation, soil loosening, weeding, plant protection and deflowering etc. as per requirement. Harvesting, cleaning, drying and weighing were done properly. Growth and leaf yield parameters i.e. plant height, branches plant ${ }^{-1}$, leaves plant ${ }^{-1}$, leaf area plant ${ }^{-1}$, fresh leaf weight and dry leaf weight were studied at 15, 30, 45 and 60 days after planting (DAP). Post-harvest soil properties were determined following standard methods (Page et al., 1982) in the Laboratories of the Departments of Agricultural Chemistry, Biochemistry, Professor Muhammed Hussain Central Laboratory (PMHCL), BAU, Mymensingh and SRDI Regional Laboratory, Dhaka. Analysis of variance (ANOVA) was done following the principle of F-statistics and the mean values were separated by using Latin Square Design (Gomez and Gomez, 1984).

\section{Results and Discussion}

\section{Effect of poultry manure (PM) on plant height}

Plant height of stevia was significantly affected by different levels of PM from 15 to 60 DAP irrespective of soils used (Fig. 1). PM application increased plant height by $51 \mathrm{~cm}$ and $45 \mathrm{~cm}$ in acid and non-calcareous soils, respectively at harvest. Plant height was significantly increased with the advancement of the growth period. Increase of plant height was slow between 0 and 15 DAP and rapid between 15 and 60 DAP. The highest plant height was measured from the plant receiving $5 \mathrm{t}$ PM ha ${ }^{-1}$ which was identical with $7.5 \mathrm{t} \mathrm{PM} \mathrm{ha}{ }^{-1}$ in acid soil but significantly different from those plants fertilized with $10 \mathrm{t} \mathrm{PM} \mathrm{ha}{ }^{-1}$ and $\mathrm{PM}_{0}$ and the lowest plant height was observed from the plant receiving no PM.

This result was in agreement with previous reports (Agboola and Obigbesan, 1975; Agboola and Omueti, 1982; Agboola and Fagbenro, 1985; Okwuagwu et al., 2003). Tiamiyu et al. (2012) reported that plant height of okra was greater in poultry manure treated soil. Ajari et al. (2003) asserted that poultry manure @ $5 \mathrm{t} \mathrm{ha}^{-1}$ treated soil could increase plant height when compared with other sources of manure. Comparatively high $\mathrm{N}$ content of poultry manure increased the vegetative growth of stevia. The increase in plant height with poultry manure was mainly due to more availability of nutrients throughout the growing season. These results were in accordance with the findings of Mitchell and Tu (2005) and Warren et al. (2006). Height increase was $82 \%$ higher in acid soil and 64\% higher in non-calcareous soil over control. 

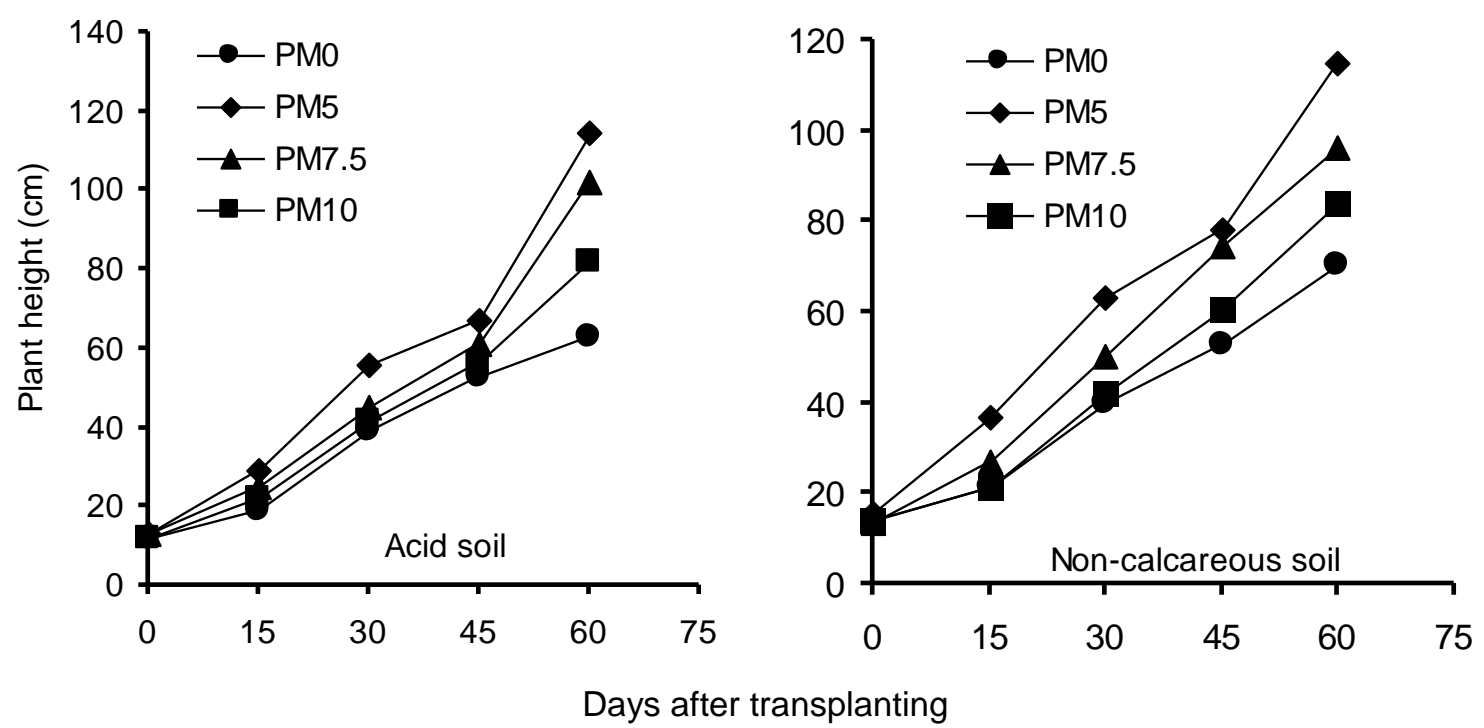

Fig. 1. Effects of different levels of poultry manure (PM) on the plant height of stevia at various DAP

Effect of poultry manure (PM) on branch number In the present study, the addition of PM significantly influenced the number of branches of stevia plant (Fig. 2). Branch numbers variably and significantly increased from 15 to 60 DAP. The increase was very rapid from 0 to $45 \mathrm{DAP}$ and then either remained constant or little increased or decreased. The highest number of branches (5.7 in both acid and non-calcareous soil) was counted from the plants receiving PM @ $5 \mathrm{t}$ $\mathrm{ha}^{-1}$ which was statistically identical with all other PM levels in non-calcareous soil except control. The lowest number of branches was counted from control. This finding was in line with Garg and Bahla (2008). They reported that poultry manure @ $5 \mathrm{t} \mathrm{ha}^{-1}$ more readily supplied $\mathrm{P}$ to plants than other organic manure sources which improved the plant cell structure and increased number of branches plant ${ }^{-1}$. PM application at all levels increased branch number by 73 to $147 \%$ in acid soil and 115 to $185 \%$ in non-calcareous soil at harvest. This finding was in agreement with that of Ojeniyi et al. (2007) who observed that application of N, P, K and animal manure increased the number of branch of tomato as compared to control.

\section{Effect of poultry manure (PM) on leaf number}

Poultry manure at different levels has significant effect on the number of leaves plant ${ }^{-1}$ both in acid and noncalcareous soils at various DAP (Fig. 3). Different levels of PM significantly influenced the number of leaves of stevia plants at all growth stages except 0 DAP irrespective of soils used. Leaf number was increased with the increasing levels of PM up to $5 \mathrm{tha}^{-1}$ and then declined with further addition.
This result was contradictory with the findings reported by Akdeniz et al. (2006) and Garg and Bahla (2008) that sorghum and vegetable crops produced maximum number of leaves when PM and sewage sludge was applied in the field@10 $\mathrm{t} \mathrm{ha}^{-1}$, respectively. At initial growth stage (0-30 DAP) leaf number increase rate was very slow while later it became rapid (30 to $60 \mathrm{DAP}$ ) irrespective of PM levels except control. Initially complete decomposition of organic manure has not been occurred which results nutrient deficiency in the soil. In the early growth stage, the number of leaves plant ${ }^{-1}$, leaf length, leaf breadth and dry weight were lower in organic manure cultivation than chemical fertilizer cultivation. But in the later growth stage the situation become quite different, there was higher number of leaves plant $^{-1}$, rapid growth and other physiological indexes. PM application at all levels increased the number of leaves by 134 to 273 in non-calcareous soil and 114 to 244 in acid soil. Maximum number of leaves was recorded with $\mathrm{PM}_{5}$ which was significantly higher than all other levels of PM in non-calcareous soil. Plants fertilized with $\mathrm{PM}_{7.5}$ and $\mathrm{PM}_{10}$ produced identical number of leaves in acid soil. The minimum number of leaves plant ${ }^{-1}$ was counted from the control irrespective of soils and growth period. In ginger, Khandkar and Nigam (1996) observed the highest plant height (39.3 $\mathrm{cm}$ ), number of leaves (20.30), tillers per plant (3.7) and yield $\left(3300 \mathrm{~kg} \mathrm{ha}^{-1}\right)$ due to application of FYM $\left(6 \mathrm{tha}^{-1}\right)$ compared to control. 

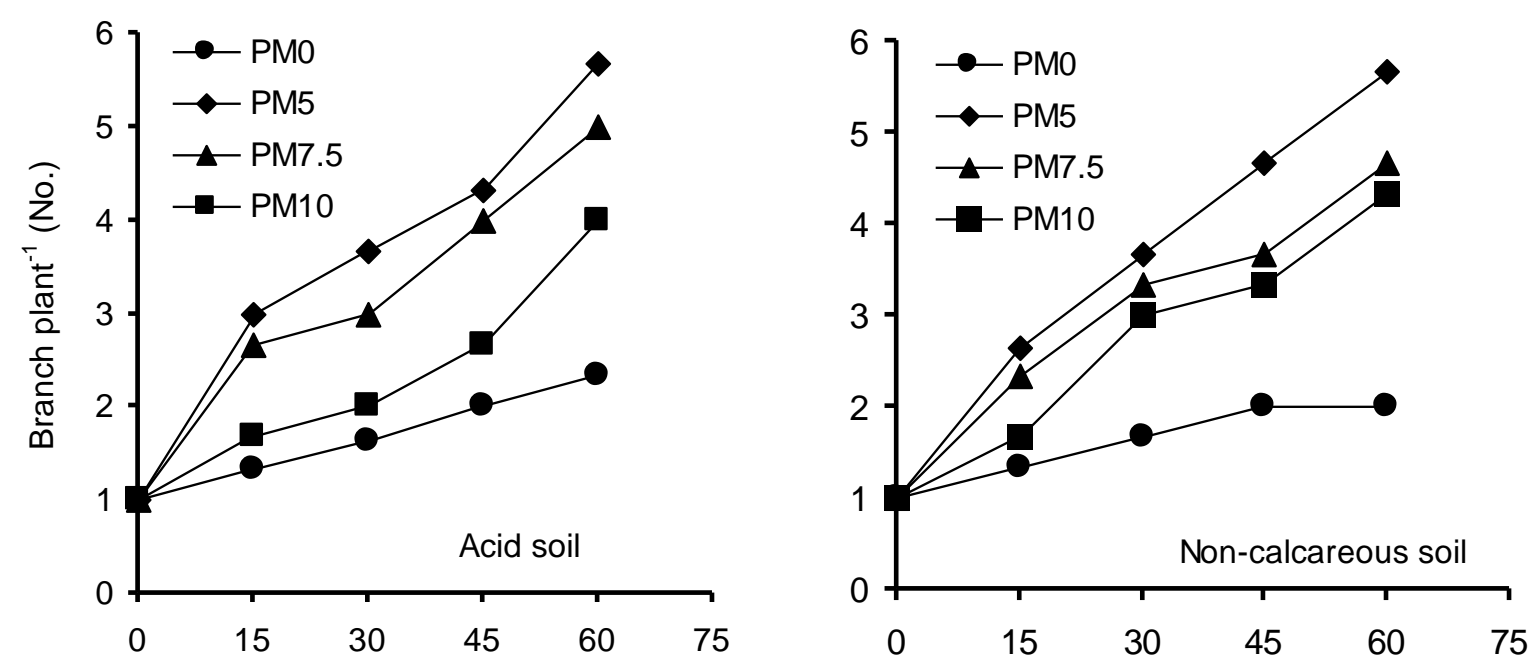

Days after transplanting

Fig. 2. Effects of different levels of poultry manure (PM) on the branch number of stevia at various DAP
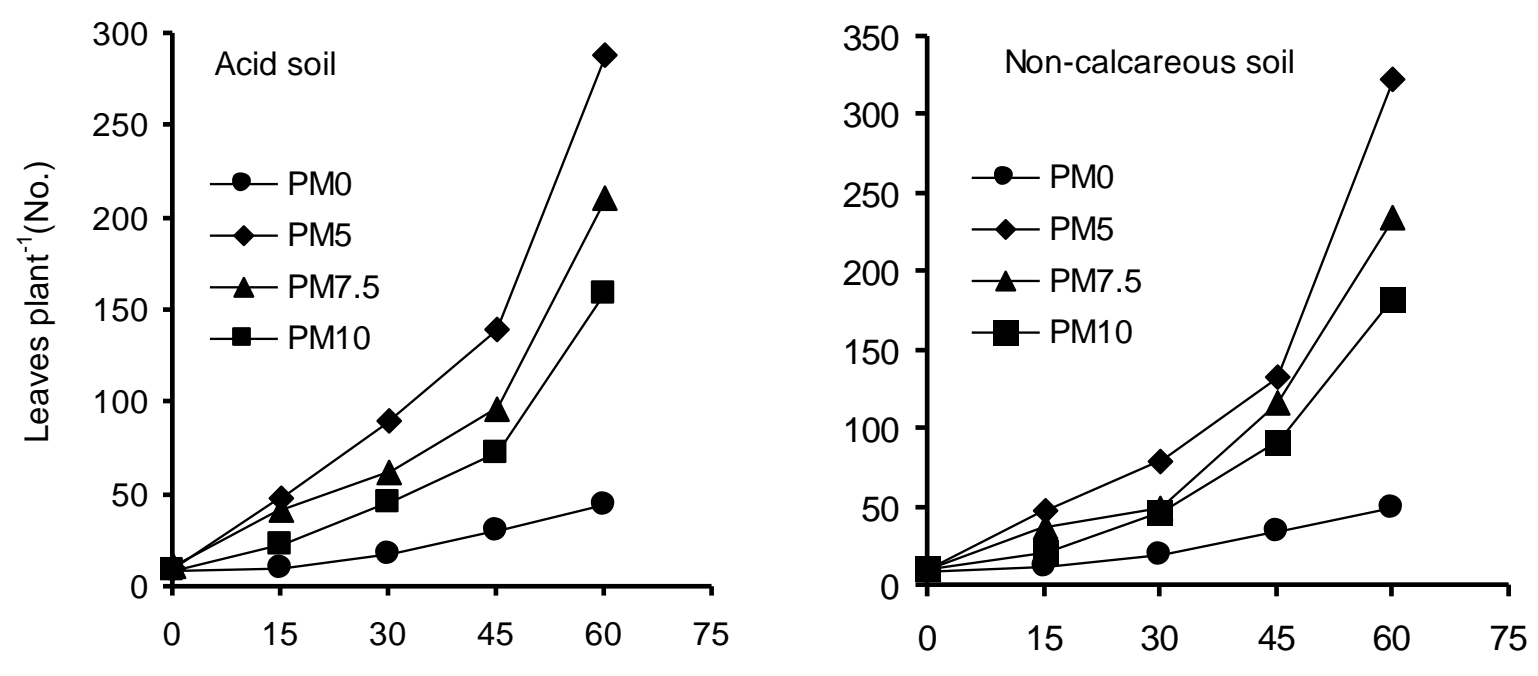

Days after transplanting

Fig. 3. Effects of different levels of poultry manure (PM) on the leaf number of stevia at various DAP

Effect of poultry manure (PM) on leaf area

The data on total leaf area plant ${ }^{-1}$ at different stages as influenced by different doses of PM have been presented in Table 1. Leaf area plant ${ }^{-1}$ responded significantly due to the application of different levels of PM. The highest total leaf area plant ${ }^{-1}\left(2303 \mathrm{~cm}^{2}\right.$ in acid soil and $2700 \mathrm{~cm}^{2}$ in non-calcareous soil) at harvest was measured from the plant receiving $5 \mathrm{t} \mathrm{PM} \mathrm{ha}{ }^{-1}$ which was significantly higher than other levels of PM. Treatment $\mathrm{PM}_{7.5}$ was responsible for second highest values $\left(1507 \mathrm{~cm}^{2}\right.$ in acid soil and $1591 \mathrm{~cm}^{2}$ in non-calcareous soil). At harvesting stage, PM application at all levels increased leaf area by 291 to $933 \%$ and 344 to $881 \%$ in acid and noncalcareous soils, respectively.
Similar findings were previously reported by OfusuAnim and Leitech (2009) that the highest leaf area was counted from the plants treated with PM @ $5 \mathrm{t} \mathrm{ha}^{-1}$ and the lowest from the zero treatment of potato cultivation. Katung et al. (1996) mentioned that PM @ $5 \mathrm{t} \mathrm{ha}^{-1}$ application easily decomposed in soil and produced the highest leaf area index of onion. PM is generally rich in manorial ingredients, early decomposer and quick supplier of nutrients. PM application in soil increased nutrient availability in the correct proportion leading to increased photosynthetic activity, thus an increase in light interception, dry matter production, accumulation and partitioning (Robert and Walker, 1989; Smith et al., 1992; Hartz et al., 1996). 
Table 1. Effects of different levels of poultry manure (PM) on leaf area, dry weight and yield increase of stevia leaves at harvest

\begin{tabular}{lcccccc}
\hline & \multicolumn{2}{c}{$\begin{array}{c}\text { Leaf area plant } \\
\left(\mathrm{cm}^{2}\right)\end{array}$} & \multicolumn{2}{c}{$\begin{array}{c}\text { Leaf dry weight } \\
(\mathrm{g} \text { plant }\end{array}$} & $\begin{array}{c}\text { Yield increase } \\
\text { over control }(\%)\end{array}$ & $\begin{array}{c}\text { Yield increase } \\
\text { over control }(\%)\end{array}$ \\
\cline { 2 - 7 } PM level & $\begin{array}{c}\text { Acid } \\
\text { soil }\end{array}$ & $\begin{array}{c}\text { Non-calcareous } \\
\text { soil }\end{array}$ & $\begin{array}{c}\text { Acid } \\
\text { soil }\end{array}$ & $\begin{array}{c}\text { Non-calcareous } \\
\text { soil }\end{array}$ & $\begin{array}{c}\text { Acid } \\
\text { soil }\end{array}$ & $\begin{array}{c}\text { Non-calcareous } \\
\text { soil }\end{array}$ \\
\hline $\mathrm{PM}_{0}$ & $223 \mathrm{~d}$ & $275 \mathrm{c}$ & $1.50 \mathrm{~d}$ & $1.55 \mathrm{~d}$ & - & - \\
$\mathrm{PM}_{5}$ & $2303 \mathrm{a}$ & $2700 \mathrm{a}$ & $8.96 \mathrm{a}$ & $9.63 \mathrm{a}$ & 497 & 521 \\
$\mathrm{PM}_{7.5}$ & $1507 \mathrm{~b}$ & $1591 \mathrm{~b}$ & $6.16 \mathrm{~b}$ & $7.12 \mathrm{~b}$ & 302 & 365 \\
$\mathrm{PM}_{10}$ & $874 \mathrm{c}$ & $1221 \mathrm{bc}$ & $4.57 \mathrm{c}$ & $5.41 \mathrm{c}$ & 204 & 249 \\
$\mathrm{CV}(\%)$ & 5 & 6 & 5.19 & 5.07 & - & - \\
$\mathrm{LSD}_{0.05}$ & 223 & 593 & 0.61 & 0.71 & - & - \\
$\mathrm{SE} \pm$ & 194 & 240 & 0.82 & 0.90 & - & - \\
\hline
\end{tabular}

$\mathrm{CV}=$ Coefficient of variance, $\mathrm{LSD}=$ Least significant difference, $\mathrm{SE} \pm=$ Standard error of means

\section{Effect of poultry manure (PM) on dry weight}

The data pertaining to dry weight of stevia leaves plant ${ }^{-1}$ at harvest as influenced by different levels of PM have been presented in Table 1. Leaf dry weight variably increased with increased PM levels up to $5 \mathrm{t} \mathrm{ha}^{-1}$ in both soils. The highest $(8.96 \mathrm{~g}$ in acid soil and $9.63 \mathrm{~g}$ in noncalcareous soil) and second highest $(6.16 \mathrm{~g}$ in acid soil and $7.12 \mathrm{~g}$ in non-calcareous soil) dry weight plant $^{-1}$ at harvest were measured from the plant receiving $5 \mathrm{t}$ and $7.5 \mathrm{t} \mathrm{PM} \mathrm{ha}^{-1}$, respectively which were significantly higher than other levels of PM. The result had not agreed with the findings reported by Detpiratmongkol et al. (2014). Detpiratmongkol et al. (2014) opined that application of $12.5 \mathrm{tha}^{-1}$ of chicken manure resulted in a significantly higher performance of growth parameters, total dry matter yield when compared to $2.5,5,7.5$ and $10 \mathrm{tha}^{-1}$, respectively. The lowest values were obtained from the control treatment. PM application at all levels increased leaf dry yield at harvest by 204 to $497 \%$ in acid soil and 249 to $521 \%$ in non-calcareous soil over control. El-Dewiny et al. (2006) showed that dry weight of radish and spinach plants increased with application of sewage sludge.

\section{Effect of poultry manure (PM) on fresh weight}

Fresh leaf weight was significantly affected by the application of PM treatments (Table 2). Leaf fresh weight was significantly increased with PM application of $5 \mathrm{t} \mathrm{ha}^{-1}$ in both soils and then declined with further addition $\left(\mathrm{PM}_{7.5}\right.$ and $\left.\mathrm{PM}_{10}\right)$. The highest fresh weight of leaves plant ${ }^{-1}$ (33.25 g in acid soil and $36.18 \mathrm{~g}$ in noncalcareous soil) was found at $5 \mathrm{tPM} \mathrm{ha}^{-1}$ and the lowest (5.05 g in acid soil and $5.50 \mathrm{~g}$ in non-calcareous soil) at control treatment. PM application at all levels increased fresh weight at harvest by 13.06 to $28.20 \mathrm{~g} \mathrm{plant}^{-1}$ in acid soil and 14.73 to $30.68 \mathrm{~g}$ plant $^{-1}$ in non-calcareous soil. Similar type of result was reported by Uka et al. (2013) in the fresh weight of okra. El-Dewiny et al. (2006) also depicted that fresh weight of radish and spinach plants increased with increased application of sewage sludge.
Table 2. Effects of different levels of poultry manure (PM) on the fresh weight of stevia leaves at harvest

\begin{tabular}{lcc}
\hline PM level & Acid soil & Non-calcareous soil \\
\hline $\mathrm{PM}_{0}$ & $5.05 \mathrm{~d}$ & $5.50 \mathrm{~d}$ \\
$\mathrm{PM}_{5}$ & $33.25 \mathrm{a}$ & $36.18 \mathrm{a}$ \\
$\mathrm{PM}_{7.5}$ & $25.12 \mathrm{~b}$ & $27.49 \mathrm{~b}$ \\
$\mathrm{PM}_{10}$ & $18.11 \mathrm{c}$ & $20.23 \mathrm{c}$ \\
$\mathrm{CV}(\%)$ & 5.18 & 5.13 \\
$\mathrm{LSD}_{0.05}$ & 2.36 & 2.57 \\
$\mathrm{SE} \pm$ & 3.17 & 3.44 \\
\hline
\end{tabular}

$\mathrm{CV}=$ Coefficient of variance, $\mathrm{LSD}=$ Least significant difference, $\mathrm{SE} \pm=$ Standard error of means

Effect of poultry manure (PM) on post-harvest fertility of soil

Application of PM significantly influenced the postharvest properties of both soils (Table $3 \mathrm{a}$ and $3 \mathrm{~b}$ ). There was significant increase in all the parameters with the increased levels of PM irrespective of soils used. The $\mathrm{pH}$ of both soils ranged from 4.9 to 5.8 in acid soil and 6.5 to 7.1 in non-calcareous soil. Wang et al. (2013) gave the same opinion that any organic material if added to the soil that will reduce soil acidity. This may be due to the fact that when organic residues (plant or animal) are added to the soil, they release organic anions which neutralize the hydrogen ion of the acid soil. The organic matter (OM) content of the post-harvest soils significantly increased due to the application of manures or composts in both soils. Organic matter content ranged from 1.7 to $2.5 \%$ in acid soil and 1.28 to $2.72 \%$ in noncalcareous soil. The contents of total $\mathrm{N}$, available $\mathrm{P}$, exchangeable $\mathrm{K}, \mathrm{Ca}, \mathrm{Mg}$, available $\mathrm{S}, \mathrm{Zn}, \mathrm{B}$ were significantly increased with the increased levels of PM up to $10 \mathrm{t} \mathrm{ha}^{-1}$ in both soils. All the nutrient contents were much higher in non-calcareous soil compared to acid soil. The available $\mathrm{P}$ content in acid soil was significantly lower than non-calcareous soil. The higher nutrient content of PM amended soil might be due to higher nutrient contents of PM compared to other amendments. However, the highest values of all the parameters were obtained from $\mathrm{PM}_{10}$ and the lowest from the initial soil. 
Table 3a. Effects of different levels of poultry manure (PM) on the fertility of post harvest soils

\begin{tabular}{lcccccccccc}
\hline \multirow{2}{*}{$\begin{array}{l}\text { PM } \\
\text { levels }\end{array}$} & \multicolumn{2}{c}{$\mathrm{pH}$} & \multicolumn{3}{c}{$\begin{array}{c}\text { Organic matter } \\
(\%)\end{array}$} & \multicolumn{2}{c}{$\begin{array}{c}\text { Total N } \\
(\%)\end{array}$} & \multicolumn{2}{c}{$\begin{array}{c}\text { Available P } \\
\left(\mu \mathrm{g} \mathrm{g}^{-1}\right)\end{array}$} & \multicolumn{2}{c}{$\begin{array}{c}\text { Exch. K } \\
\left(\mathrm{cmol} \mathrm{kg}^{-1}\right)\end{array}$} \\
\cline { 2 - 11 } & $\mathrm{AS}$ & $\mathrm{NS}$ & $\mathrm{AS}$ & $\mathrm{NS}$ & $\mathrm{AS}$ & $\mathrm{NS}$ & $\mathrm{AS}$ & $\mathrm{NS}$ & $\mathrm{AS}$ & $\mathrm{NS}$ \\
\hline $\mathrm{PM}_{0}$ & $4.9 \mathrm{~b}$ & $6.5 \mathrm{~b}$ & $1.70 \mathrm{~b}$ & $1.28 \mathrm{~b}$ & $0.10 \mathrm{~b}$ & $0.12 \mathrm{~b}$ & $2.83 \mathrm{c}$ & $10.00 \mathrm{~cd}$ & $0.18 \mathrm{~b}$ & $0.15 \mathrm{~b}$ \\
$\mathrm{PM}_{5}$ & $5.3 \mathrm{a}$ & $6.7 \mathrm{a}$ & $1.92 \mathrm{~b}$ & $1.96 \mathrm{a}$ & $0.19 \mathrm{ab}$ & $0.19 \mathrm{~b}$ & $4.64 \mathrm{~b}$ & $14.10 \mathrm{bc}$ & $0.22 \mathrm{~b}$ & $0.20 \mathrm{ab}$ \\
$\mathrm{PM}_{7.5}$ & $5.6 \mathrm{a}$ & $6.8 \mathrm{a}$ & $2.24 \mathrm{a}$ & $2.26 \mathrm{a}$ & $0.23 \mathrm{a}$ & $0.23 \mathrm{a}$ & $7.62 \mathrm{a}$ & $18.20 \mathrm{~b}$ & $0.26 \mathrm{ab}$ & $0.25 \mathrm{a}$ \\
$\mathrm{PM}_{10}$ & $5.8 \mathrm{a}$ & $7.1 \mathrm{a}$ & $2.50 \mathrm{a}$ & $2.72 \mathrm{a}$ & $0.28 \mathrm{a}$ & $0.26 \mathrm{a}$ & $9.91 \mathrm{a}$ & $21.30 \mathrm{a}$ & $0.30 \mathrm{a}$ & $0.28 \mathrm{a}$ \\
$\mathrm{CV}_{(\%)}$ & 3.1 & 3.3 & 3.86 & 6.92 & 9.62 & 7.62 & 10.55 & 5.73 & 3.90 & 5.36 \\
$\mathrm{LSD}$ & 0.5 & 0.9 & 0.25 & 0.35 & 0.59 & 0.15 & 0.91 & 2.03 & 0.04 & 0.06 \\
$\mathrm{SE} \pm$ & 0.2 & 0.2 & 0.07 & 0.09 & 0.01 & 0.01 & 0.63 & 0.95 & 0.02 & 0.03 \\
\hline
\end{tabular}

$\mathrm{AS}=$ Acid soil, $\mathrm{NS}=$ Non-calcareous soil, $\mathrm{CV}=$ Coefficient of variance, $\mathrm{LSD}=$ Least significant difference, $\mathrm{SE} \pm=$ Standard error of means, Exch. $=$ Exchangeable

Table 3b. Effects of different levels of poultry manure (PM) on the fertility of post-harvest soils

\begin{tabular}{|c|c|c|c|c|c|c|c|c|c|c|}
\hline \multirow{2}{*}{$\begin{array}{l}\text { PM } \\
\text { levels }\end{array}$} & \multicolumn{2}{|c|}{$\begin{array}{c}\text { Available } S \\
\left(\mu \mathrm{g} \mathrm{g}^{-1}\right)\end{array}$} & \multicolumn{2}{|c|}{$\begin{array}{c}\text { Exch. Ca } \\
\left(\mathrm{cmol} \mathrm{kg}^{-1}\right)\end{array}$} & \multicolumn{2}{|c|}{$\begin{array}{c}\text { Exch. Mg } \\
\left(\mathrm{cmol} \mathrm{kg}^{-1}\right)\end{array}$} & \multicolumn{2}{|c|}{$\begin{array}{c}\text { Available } \mathrm{Zn} \\
\left(\mu \mathrm{g} \mathrm{g}^{-1}\right)\end{array}$} & \multicolumn{2}{|c|}{$\begin{array}{c}\text { Available B } \\
\left(\mu \mathrm{g} \mathrm{g}^{-1}\right)\end{array}$} \\
\hline & AS & NS & AS & NS & AS & NS & AS & NS & AS & NS \\
\hline $\mathrm{PM}_{0}$ & $13.06 \mathrm{~d}$ & $13.00 \mathrm{~d}$ & $0.15 b$ & $2.10 \mathrm{~b}$ & $0.60 \mathrm{~b}$ & $1.20 \mathrm{~b}$ & $1.30 \mathrm{~b}$ & $0.80 \mathrm{~b}$ & $0.33 b$ & $0.23 c$ \\
\hline $\mathrm{PM}_{5}$ & $16.45 \mathrm{c}$ & $18.23 \mathrm{c}$ & $2.17 \mathrm{a}$ & $7.94 a$ & $0.88 \mathrm{a}$ & $3.50 \mathrm{a}$ & $1.75 \mathrm{ab}$ & $0.98 \mathrm{~b}$ & $0.65 b$ & $0.38 \mathrm{~b}$ \\
\hline $\mathrm{PM}_{7.5}$ & $19.35 b$ & $26.68 b$ & $3.52 \mathrm{a}$ & $9.18 \mathrm{a}$ & $1.10 \mathrm{a}$ & $5.65 \mathrm{a}$ & $1.93 \mathrm{a}$ & $1.16 \mathrm{~b}$ & $0.88 \mathrm{a}$ & $0.56 \mathrm{ab}$ \\
\hline $\mathrm{PM}_{10}$ & $22.10 \mathrm{a}$ & $30.27 \mathrm{a}$ & $4.79 a$ & $11.52 \mathrm{a}$ & $1.31 \mathrm{a}$ & 7.75a & $2.18 \mathrm{a}$ & $1.38 \mathrm{a}$ & $0.98 \mathrm{a}$ & $0.95 \mathrm{a}$ \\
\hline $\mathrm{CV}(\%)$ & 4.32 & 12.21 & 7.85 & 4.26 & 5.17 & 9.35 & 7.30 & 4.30 & 4.39 & 7.81 \\
\hline $\mathrm{LSD}_{0.05}$ & 1.19 & 2.03 & 0.37 & 0.88 & 0.08 & 0.41 & 0.63 & 0.31 & 0.12 & 0.08 \\
\hline $\mathrm{SE} \pm$ & 0.51 & 2.19 & 0.32 & 0.46 & 0.02 & 0.40 & 0.09 & 0.04 & 0.09 & 0.04 \\
\hline
\end{tabular}

$\mathrm{AS}=$ Acid soil, NS = Non-calcareous soil, CV = Coefficient of variance, $\mathrm{LSD}=$ Least significant difference, $\mathrm{SE} \pm=$ Standard error of means, Exch. $=$ Exchangeable

The present findings were in conformity line with Savithri et al. (1991) who reported that application of $6.25 \mathrm{t} \mathrm{ha}^{-1}$ poultry manure to the first crop of sorghum had significant residual effect on succeeding crop yield and that also increased the nutrient content of the soil. Senthilkumar (2002), Sudhakara (2005) and Ibeawuchi et al. (2006) obtained similar results in African marigold, coleus and continuous cropping system, respectively.

\section{Conclusion}

From the investigation, it appeared that PM gave significant positive response towards all the parameters studied. The best PM dose was $5 \mathrm{t} \mathrm{ha}^{-1}$ for all the parameters assessed except post-harvest soil conditions. In case of post-harvest soil status the highest values of all the parameters were obtained from $\mathrm{PM}_{10}$. Finally, it would be recommended for the farmers that PM @ 5 tha $^{-1}$ can be applied to obtain maximum growth and yield of stevia and PM @ $10 \mathrm{tha}^{-1}$ for maintaining soil fertility in agro-climatic condition of Bangladesh.

\section{Acknowledgement}

We express our sincere thanks and gratitude to the concerned authority of Bangladesh Agricultural Research Council (BARC), Farmgate, Dhaka for financial support.

\section{References}

Agboola, A.A. and Fagbenro, J.A. 1985. Soil organic matter and its management in the humid tropics with particular reference to Nigeria. Proceedings ISSS organized by Society of Soil Science of Nigeria, 21-26 July, Ibadan, pp. 215-283.
Agboola, A.A., Obigbesan, G.O. and Fayemi, A.A.A. 1975. Interrelations between organic and mineral fertilizer in the tropical rainforest of Western Nigeria. In: Organic materials as fertilizers. FAO Soil Bulletin No. 27, pp. 337-351.

Agboola, A.A. and Omueti, J.A.I. 1982. Soil fertility problems and its management in tropical Africa. Proceedings of International conference on land clearing and development, IITA, Ibadan, Nigeria, pp. 350-365.

Ajari, O., Tsado, L.E.K., Oladiran, J.A. and Salako, E.A. 2003. Plant height and fruit yield of okra as affected by field application of fertilizer and organic matter in Bida, Nigeria. Nigerian Agric. J.,34: 74-80.

Akdeniz, H., Yılmaz, I., Bozkurt, M.A. and Keskin, B. 2006. The effects of sewage sludge and nitrogen applications on grain sorghum grown (Sorghum vulgare L.) in Van-Turkey. Pol. J. Environ. Stud., 15: 19-26.

Boateng, S., Zickermann, A.J. and Kornaharens, M. 2006. Effect of poultry manure on growth and yield of maize. West African J. Appl. Ecol., 9: 1-11.

Detpiratmongkol, S., Ubolkerd, T. and Yoosukyingstaporn, S. 2014. Effects of chicken, pig and cow manures on growth and yield of Kalmegh (Andrographis paniculata Nees). $J$. Agric.Tech., 10: 475-482.

El-Dewiny, C.Y., Moursy, K.S. and El-Aila, H.I. 2006. Effect of organic matter on the release and availability of phosphorus and their effects on spinach and radish plants. Res. J. Agric. Biol. Sci., 2: 103-108.

Garg, S. and Bahla, G.S. 2008. Phosphorus availability to maize as influenced by organic manures and fertilizer $\mathrm{P}$ associated phosphatase activity in soils. Bioresour. Technol., 99: 5773-5777.

Gilley, J.E.A.L.M.R. 2000. Runoff and soil loss as affected by the application of manure. Trans. ASAE, 43(6): 1583-1588.

Gomez, K.A. and Gomez, A.A. 1984. Statistical Procedure for Agricultural Research. $2^{\text {nd }}$ edn. International Rice Research Institute. Los Banos, Philippines. pp. 207-215. 
Gruhn, P., Golett, F. and Yudelman, M. 2000. Integrated Nutrient Management, Soil Fertility and Sustainable Agriculture: Current Issues and Future Challenges. Food, Agriculture and Environment Discussion Paper 32. International Food Policy Research Institute, Washington DC, USA.

Hartz, T.K., Coasta, F.J. and Schrander, W.L. 1996. Suitability of composted green waste for horticultural uses. Hort. Sci., 31: 961-964.

Hillel, D. 1998. Environmental Soil Physics. Academic Press, New York, USA, p. 771.

Ibeawuchi, I.I , Onweremadu, E.U. and Oti, N.N. 2006. Effects of poultry manure on green (Amarathus cruentus) and waterleaf (Talinum trinagulare) on Degraded Ultisol of Owerri Southeastern Nigeria. J. Anim. Vet. Adv., 5: 53-56.

IFOAM. 2008. Basic Standards for Organic Agriculture and Processing. IFOAM (International Federation for Organic Agriculture Movement) Head Office, Oko Zentrum Imbash Tholey- Tholey.

Katung, M.D., Olanrewaju, J.D., Gupta, U.S. and Kureh, I. 1996. Fruit and seed yields of okra as influenced by farm yard manure and nitrogen fertilizer. In: Proceedings of 14th HORTSON Conference, Ago-Iwoye, 1-4 April, pp. 210.

Khandkar, U.R. and Nigam, K.B. 1996. Effect of farm yard manure and fertility level on growth and yield of ginger (Zingiber officinale) Indian J. Agri. Sci., 66 (9): 549-550.

Lobo, V., Patil, A., Phatak, A. and Chandra, N. 2010. Free radicals, antioxidants and functional foods: Impact on human health. Pharmacogn. Rev., 4: 118-126.

Mitchell, C.C. and Tu, S. 2005. Long-term evaluation of poultry litter as a source of nitrogen for cotton and corn. Agron. J., 97 : 399-407.

Moore, P. A., Jr. and D. R. Edwards. 2005. Long-term effects of poultry litter, alum-treated litter, and ammonium nitrate on aluminum availability in soils. J. Environ. Qual., 34(6): 2104-2111.

Ofusu-Anim, J. and Leitech, M. 2009. Relative efficacy of manures in spring barley production. Aust. J. Crop Sci., 3: 13-19.

Ojeniyi, S.O., Awodun, M. A. and Odedina, S. A. 2007. Effect of animal manure amended spent grain and cocoa husk on nutrient status, growth and yield of tomato. Middle East $J$. Sci. Res., 2(1): 33-36.

Okwuagwu, M.I., Alleh, M.E. and Osemwota, I.O. 2003. The effect of organic and inorganic manure on soil properties and yield of okra in Nigeria. Proceedings of African Crop Science Conference, 6: 390-393.

Page, A.L., Miller, R.H. and Keeney, D.R. (eds). 1982. Method of Soil Analysis, Part-2 Chemical and Microbiological Properties, $2^{\text {nd }}$ edn., American Society of Agronomy, Inc. Madison, Wisconsin, USA.

Pawar, R.S., Krynitsky, A.J. and Rader, J.I. 2013. Sweeteners from plants - with emphasis on Stevia rebaudiana (Bertoni) and Siraitia grosvenorii (Swingle). Anal. Bioanal. Chem., 405: 4397-4407

Risso, D., Morini, G., Pagani, L., Quagliariello, A., Giuliani, C., De Fanti, S., Sazzini, M., Luiselli, D. and Tofanelli, S. 2014. Genetic signature of differential sensitivity to stevioside in the Italian population. Genes Nutr., 9: 401.

Robert, K.M.H. and Walker, A.J. 1989. An introduction to the Physiology of Crop Yield. John Wiley and Sons Inc., New York.

Savithri, P., Subbiah, S., Malarvili, P. and Gopalsamy, A. 1991. Effect of coir pith based poultry litter on yield and nutrient uptake by sorghum cowpea cropping system. Proceedings of the Seminar on Utilization of Coirpith in Agriculture, November 20, 1991, TNAU, Coimbatore.
Senthilkumar, B. 2002. Effect of integrated nutrient management and plant density on growth, yield and quality of African marigold (Tagetus minuta) M.Sc. (Hort.) Thesis, University of Agricultural Sciences, Bangalore.

Smith, S.R., Hall, J.E. and Hadley, P. 1992. Composting sewage sludge wastes in relation to their suitability for use as fertilizer materials for vegetable crop production. Acta Horticulturae, 302: 203-216.

Stefan, T. 2003. Organic Agriculture: Sustainability market policies. $\mathrm{CAB}$ Organization for Economic Co-operation and Development. p. 95.

Sudhakara, H.A. 2005. Standardization of organic farming practices in coleus. M.Sc. (Hort.) Thesis, University of Agricultural Sciences, Bengaluru, India.

Tejada, M., Hernandez, M. T. and Garcia, C. 2006. Application of two organic amendments on soil restoration: effects on the soil biological properties. J. Environ. Qual., 35(4): 1010-1017.

Tiamiyu, R.A., Ahmed, H.G. and Muhammad, A.S. 2012. Effect of sources of organic manure on growth and yields of okra (Abelmoschus esculentus L.) in Sokoto, Nigeria. Nig. J. Basic Appl. Sci., 20: 213-216.

Uka, U.N., Chukwuka, K.S. and Iwuagwu, M. 2013. Relative effect of organic and inorganic fertilizers on the growth of okra (Abelmoschus esculentus L.) Moeuch. J. Agric. Sci., 58: 159-166.

Varvel, G. E. 2000. Crop rotation and nitrogen effects on normalized grain yields in a long term study. Agron. J., 92(5): 938-941.

Wang, Y., Tang, C., Wu, J., Liu, X. and Xu, J. 2013. Impact of organic matter addition on $\mathrm{pH}$ change of paddy soil. J. Soil Sediment, 13: 12-13.

Warren, J.G., Phillips, S.B., Mullins, G.L., Keahey, D. and Penn, C.J. 2006. Environmental and production consequences of using alum-amended poultry litter as a nutrient source for corn. $J$. Environ. Qual., 35: 172-182.

Whalen, J. K., C. Chang, G. W. Clayton and J. P. Carefoot. 2000. Cattle manure amendments can increase the $\mathrm{pH}$ of acid soils. Sci. Soc. Am. J., 64(3): 962-966.

Yang, S. M., Li, F. M., Malhi, S. S., Wang, P., Suo D. and Wang. J. 2004. Long-term fertilization effects on crop yield and nitrate nitrogen accumulation in soil in Northwestern China. Agron. J., 96(4): 1039-1049.

Zaman, M.M. 2015a. Nutrient requirement leaf yield and stevioside content of stevia (Stevia rebaudiana Bertoni) in some soil types of Bangladesh. PhD Thesis, Department of Agricultural Chemistry, Bangladesh Agricultural University, Mymensingh.

Zaman, M.M., Chowdhury, M.A.H. Islam, M.R. and Uddin, M.R. 2015b. Effects of vermicompost on growth and leaf biomass yield of stevia and post-harvest fertility status of soil. J. Bangladesh Agril. Univ., 13(2): 169-174.

Zaman, M.M., Chowdhury, M.A.H., Mohiuddin, K.M. and Chowdhury, T. 2016a. Nitrogen requirement and critical N content of stevia grown in two contrasting soils of Bangladesh. Res. Agric. Livest. Fish., 3: 87-97.

Zaman, M.M., Chowdhury, M.A.H., Chowdhury, T. and Hasan, A.B.M.M. 2016b. Critical leaf $\mathrm{S}$ concentration and S requirement of stevia grown in two different soils of Bangladesh. Fundam. Appl. Agric., 1(3): 106-111.

Zaman, M.M., Chowdhury, T., Rahman, M.A. and Chowdhury, M.A.H. 2017a. Phosphorus use efficiency and critical P content of stevia grown in acid and non-calcareous soils of Bangladesh. Res. Agric. Livest. Fish., 4 (2):55-68.

Zaman, M.M., Chowdhury, T., Rahman, M.A. and Chowdhury, M.A.H. 2017b. Potassium requirement for leaf biomass yield and K nutrition of stevia. Fundam. Appl. Agric., 2(3): 297-302. 